\title{
Human spermatozoa: revelations on the road to conception
}

\section{R. John Aitken}

Address: Priority Research Centre in Reproductive Science, Discipline of Biological sciences, Faculty of Science and IT, University of Newcastle, Callaghan, NSW 2308, Australia

Email: john.aitken@newcastle.edu.au

Fl000Prime Reports 2013, 5:39 (doi:10.12703/P5-39)

This is an open-access article distributed under the terms of the Creative Commons Attribution-Non Commercial License (http://creativecommons.org/licenses/by-nc/3.0/legalcode), which permits unrestricted use, distribution, and reproduction in any medium, provided the original work is properly cited. You may not use this work for commercial purposes.

The electronic version of this article is the complete one and can be found at: http://fl 000.com/prime/reports/b/5/39

\begin{abstract}
Human spermatozoa are highly complex specialized cells designed to survive a long and perilous journey from the site of insemination to the upper reaches of the female reproductive tract where fertilization occurs. During this journey, these cells have to run the gauntlet laid down by the female immune system and time their physiological maturation so that as soon as an egg appears in the Fallopian tube, they are equipped to recognize this cell and participate in a remarkable cascade of cellular interactions culminating in fertilization. Despite their high level of specialization, human spermatozoa are notoriously inadequate and appear to be major contributors to the poor fertility that characterizes our species. Defective spermatozoa are also known to have a major impact on the progress of pregnancy and the health trajectory of the offspring, resulting in paternally mediated increases in miscarriage rate and a range of diseases in the progeny, including dominant genetic diseases and cancer. The causes of defective sperm function are complex and involve both genetic and environmental impacts, as well as paternal age. Where genetic factors are involved, there is a concern that the widespread use of assisted conception technologies will serve to enhance the retention of poor fertility genes in the population such that the more we use assisted reproductive technologies in one generation the more we shall need them in the next. These observations may have important implications for the health and well-being of children and for the provision of reproductive healthcare services for future generations.
\end{abstract}

\section{Introduction}

While human spermatozoa are commonly perceived as dispensable ciphers of limited clinical or scientific significance, these cells actually perform the most remarkable biological feats in their quest to escape recognition by the female immune system and fertilize the egg. As a result of our relative indifference to their biology, we know very little about the molecular mechanisms that underpin the differentiation and function of spermatozoa, even though such information is of clear relevance to the origins of male infertility and the development of novel approaches to male contraception.

Both of these subject areas should be the focus of concern. On the one hand, defective sperm function is the largest single defined cause of human infertility [1] affecting at least 1 in 20 males of reproductive age [2] and on the other hand, there are no reversible methods of male fertility regulation available, even though the social and clinical need for such methods is perfectly evident [3-5]. One of the few things we do know about human spermatozoa is that compared with most other species, they are of extremely poor quality as judged by their morphological appearance, motility and functional competence (Figures 1 and 2). According to the most recent World Health Organisation (WHO) guidelines, even in normal, fertile men, up to $96 \%$ of the spermatozoa will be abnormally formed, up to $68 \%$ will be immotile and up to $42 \%$ will be dead [6]. The only other primate to exhibit such poor quality semen is our close relative the gorilla, suggesting that the human condition may, in part, reflect our evolutionary heritage [7]. The latter may in turn reflect our preference for monogamous mating systems associated with low levels 
Figure I. Comparison of sperm morphology in human and stallion

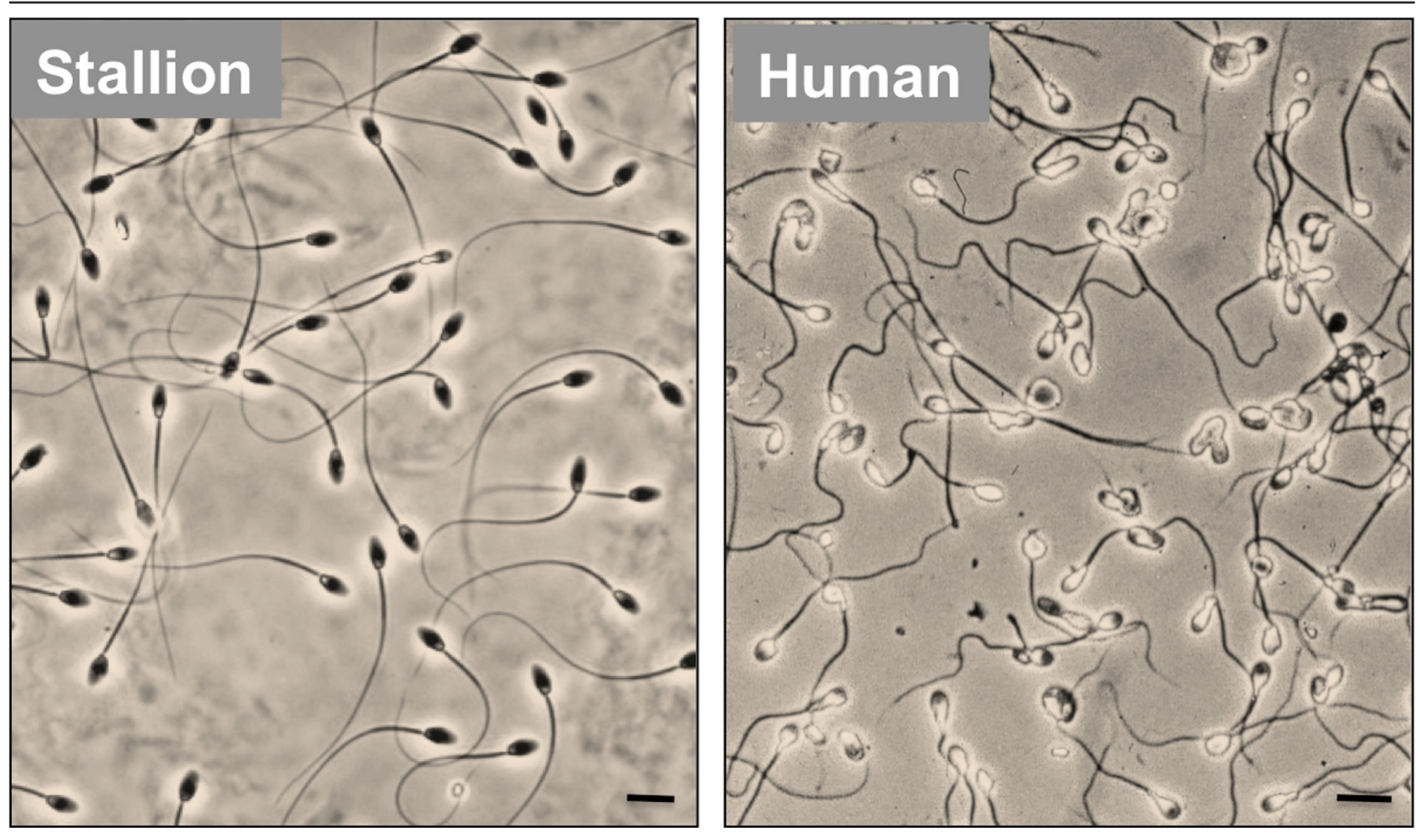

The stallion is typical of a majority of mammalian species in that a majority of the spermatozoa generated by this species exhibit a normal sperm morphology with very little intercellular variation. By contrast, human spermatozoa are characterized by extremely poor morphology featuring considerable intercellular variation. Scale bar $=5 \mu \mathrm{m}$.

of sperm competition [8]. However, there may be other reasons why the quality of these cells might be so seriously impaired and why controversial evidence is emerging that semen quality is declining in our species with the march of time [9-12]. The purpose of this article is to review the range of genetic and environmental factors that might be impinging on human sperm quality and to consider the implications for reproductive health care delivery in the future.

\section{The demographic transition, genetic selection and infertility}

One contributing factor, which has received little attention, is that poor semen quality might be the price we pay for high levels of economic growth. Impoverished societies at the earliest stages of socio-economic development are typically characterized by high rates of perinatal infant mortality and large family sizes. Thus, many of the world's poorest nations exhibit an average family size exceeding seven, in association with high rates of infant mortality and low rates of survival to reproductive age $[13,14]$. Under such conditions, there will inevitably be intense selection pressure on high fertility genes. Thus, in poorly developed societies, you have to be sufficiently fertile to have a large family if a fraction of your offspring is going to survive to reproductive age and pass your genotype, with its good fertility genes, on to the next generation. By contrast, in a developed country with low rates of infant mortality and widely available assisted conception technology, there is little to no selection pressure on good fertility genes. If a male patient can only manage to generate a single spermatozoon, there is still every chance that conception will be possible if intracytoplasmic sperm injection (ICSI) - a process involving the direct injection of a sperm into the oocyte cytoplasm - is used as the insemination procedure. Under these conditions, which are relatively common in developed countries, poor fertility genes will inevitably be passed on to the next generation.

Concrete examples of this effect can be found in the treatment of men with Klinefelter's syndrome or AZFC deletions. Male patients with non-mosaic Klinefelter's disease possess a 47XXY sex chromosome constitution and were traditionally thought to be infertile. However, 
Figure 2. The remarkable anatomy and life history of a sperm cell

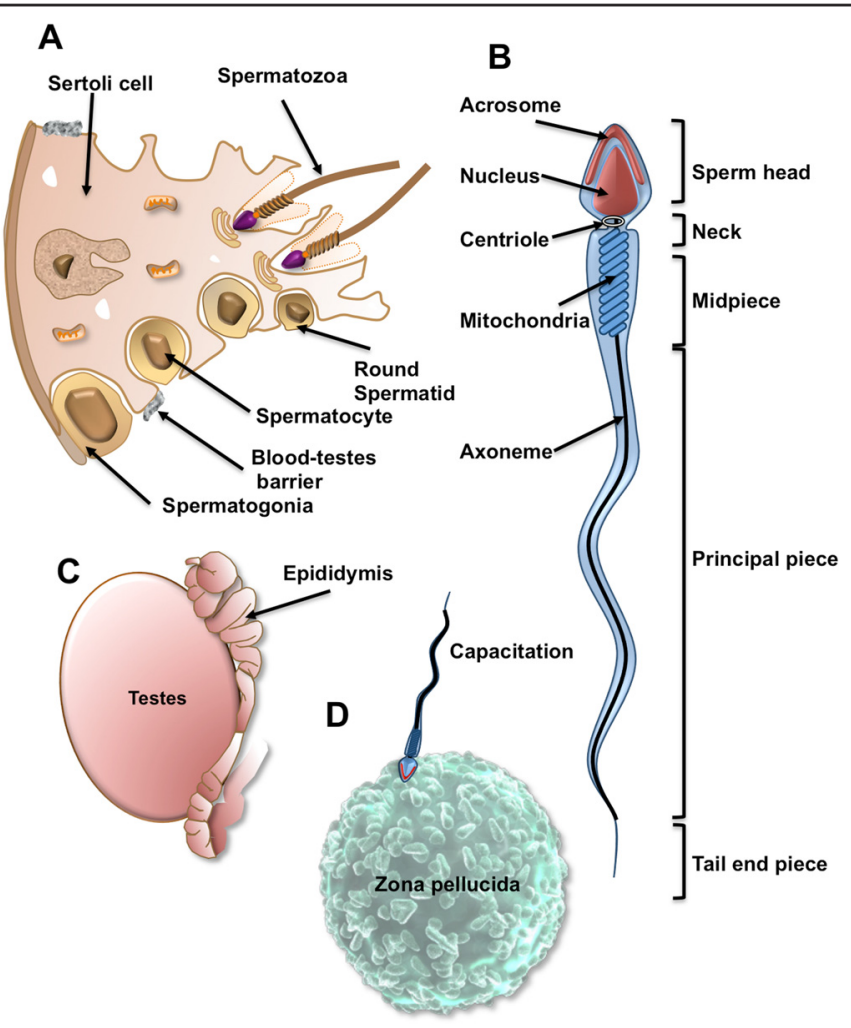

(A) Spermatogenesis takes place within the germinal epithelium of the testes. Spermatogonia pass across the blood-testes barrier, enter meiosis and differentiate into spermatocytes and ultimately haploid round spermatids. The latter then metamorphose into spermatozoa in a remarkable process known as spermiogenesis, which achieves the dramatic morphological transformation of the germ cell in the complete absence of de novo gene transcription. (B) The fully differentiated spermatozoon comprises a sperm head (containing the nucleus and a secretory vesicle, the acrosome, which plays a key role in fertilization), the neck (containing a centriole which orchestrates all cell division in the embryo), the midpiece (containing the mitochondria, which contribute to the energy demands of the cell but are destroyed in the oocyte following fertilization), the principle piece, which propels the spermatozoon towards the oocyte, changing both the amplitude and frequency of the flagellar beat pattern as it does in order to generate a specialized form of motility in the immediate vicinity of the oocyte (hyperactivation), which facilitates penetration of the vestments surrounding the oocyte) and the tail end piece. (C) Spermatozoa leaving the testes are immature and completely lacking in functional competence. Functionality is only acquired as these cells pass through a complex excurrent duct system known as the epididymis. In this organ, post-translational changes to the protein composition of the spermatozoa confer upon these cells the potential to exhibit vigorous motility and achieve fertilization. (D) Realization of this potential for fertilization involves a further series of changes in the spermatozoa as these cells ascend the female reproductive tract. These changes are termed "capacitation" and allow the spermatozoa to express receptors for the shell that encases the oocyte, the zona pellucida, respond to this unique cell-cell recognition event by undergoing the acrosome reaction and express the hyperactivated motility needed to penetrate through the zona pellucida to the vitelline membrane of the egg, where sperm-egg fusion occurs.

spermatozoa can be recovered, either from the ejaculates of young Klinefelter's patients or, if this fails, by examining biopsy material from the testes [15]. A majority of these recovered spermatozoa are $23 \mathrm{X}$ or 23Y; however, rates of aneuploidy are elevated in such cells, with one of the most common chromosomal mutations being $24 \mathrm{XY}[16,17]$. If such an aneuploid spermatozoon were to be used for injection into the oocyte during an assisted conception cycle involving ICSI, any male offspring would inevitably exhibit the Klinefelter's syndrome found in their father, as well as the infertility associated with this condition.
Exactly the same vertical transmission of a major mutation associated with infertility occurs during the treatment of patients with deletions on their Y chromosome using ICSI [16]. Since such deletions render the bearer infertile, we must conclude that they occur spontaneously in the father's germ line or, possibly, are generated in the oocyte as a result of the aberrant repair of fragmented sperm DNA following fertilization [18]. Currently, the most favoured hypothesis is that such aberrations arise because of the erroneous recombination of palindromic sequences flanking major genes during an unusual intra-chromosomal homologous 
recombination procedure that is designed to stabilize the Y chromosome throughout its isolated existence [19]. Although factors potentially capable of influencing the incidence of such Y chromosome mutations have not yet been described, the fact that $3-20 \%$ of infertility patients exhibit such deletions tells us that genetic errors on the $\mathrm{Y}$ chromosome are not a particularly rare event [20-22]. Such deletions have been classified into three groups $(\mathrm{AZFa}, \mathrm{AZFb}, \mathrm{AZFC})$ depending on the region of the $Y$ chromosome experiencing deletion. In the case of AZFa and AZFb deletions, the result is usually complete azoospermia, with no current potential for treatment. However, patients with AZFc deletions are typically characterised by severe oligozoospermia, with small numbers of spermatozoa recoverable from the ejaculate or from testicular biopsy material. As in the treatment of Klinefelter's syndrome, such assisted conception procedures will allow otherwise infertile males to sire a child. However, it has to be appreciated that if the child is a male, it will inherent the mutated paternal $\mathrm{Y}$ chromosome and, with it, the infertility associated with this condition. So, the use of assisted conception procedures to treat the infertility associated with Klinefelter's syndrome and AZFc deletions, may permit the transfer of an impaired fertility phenotype to the offspring. If other genetic factors turn out to be a major cause of human male infertility (and this is highly possible $[22,23])$, then this pattern will be repeated and the transmission of poor fertility genes to subsequent generations will be facilitated. Given the high rate of recourse to assisted conception therapy in developed countries (one in 30 babies in Australia is now the product of assisted conception), it is likely that overall fertility levels will fall as a consequence. Indeed, there is inevitability to the conclusion that the more we use assisted conception in one generation, the more we shall need it in the next.

\section{Impact of age and lifestyle on spermatozoa and future children}

In addition to the long-range impact of genetic selection on the future fertility of the affluent, environmental factors can have a more direct influence on the mutational load carried by the offspring. For example, Linschooten et al. [24] employed a detailed analysis of selected minisatellite loci (CEB1 and B6.7) to demonstrate that high gross yearly income, as a surrogate measure of a healthy lifestyle, was inversely correlated with mutation rates in the offspring. Conversely, paternal smoking in the 6 months before pregnancy was positively correlated with mutation rate. The influence of age and environmental factors, such as smoking, on paternally mediated disorders of development may not only involve genetic mutations, male-mediated epimutations may also have a profound impact on the health and well-being of the offspring. Epigenetic modifications to the male germ line during gametogenesis are designed to silence unwanted paternally imprinted genes in preparation for future embryonic development and also to regulate the postmeiotic expression of genes during late spermatogenesis [25]. Disruptions of this carefully regulated pattern of DNA methylation are seen in response to advanced paternal age and defective sperm function - both of which lead to a global hypermethylation of sperm DNA $[26,27]$, which may, in turn, have a major impact on the normality of subsequent embryogenesis. In addition, spermatozoa may also carry specific RNA species into the embryo, including mRNA and non-coding RNA molecules that, if damaged, may significantly influence the trajectory of subsequent embryonic development [28].

Thus, male factors, including age and environmental (including lifestyle) factors, may significantly disrupt embryonic development by not only inducing genetic damage in the fertilizing spermatozoon but also influencing epigenetic factors, including chromatin structure and RNA composition. How such genetic and epigenetic damage is ultimately induced in the male germ line has not been fully resolved. Nevertheless, research over the past decade has demonstrated that one of the key mediators of such damage, with the potential to attack both the DNA and the epigenetic role of sperm RNA, is oxidative stress [29].

\section{Oxidative stress}

A characteristic feature of mammalian spermatozoa is that these cells possess a cytoplasmic space that is severely restricted in terms of both volume and distribution (Figure 2). One consequence of this unusual architecture is that spermatozoa are poorly endowed with intracellular antioxidant defence enzymes with which to scavenge the free radicals generated as an inadvertent consequence of sperm metabolism. Such susceptibility to oxidative stress is compounded by the presence of abundant substrates for free radical attack in spermatozoa including the polyunsaturated fatty acids that abound in the sperm plasma membrane and the DNA in the sperm nucleus [30,31]. The latter is actually relatively resistant to oxidative attack by virtue of its highly compact nature and, possibly, the presence of protamines, which may chelate metals involved in catalyzing DNA fragmentation $[32,33]$. However, the inert nature of sperm chromatin also means that these cells have very limited capacity for DNA repair. Indeed the only repair capacity they are known to possess is the first enzyme in the base excision repair pathway, OGG1 (8-Oxoguanine glycosylase) [34]. This enzyme recognizes the major product of oxidative attack on DNA, 8-hydroxy, 2'-deoxyguanosine (8OHdG), 
and cleaves this base adduct out of the DNA backbone, leaving an abasic site and liberating 8OHdG to the cell exterior. The next enzyme in the base excision repair pathway, APE1 (Apurinic/apyrimidinic endonuclease), which recognizes the abasic site and creates a $3^{\prime} \mathrm{OH}$ group at the strand break in preparation for the insertion of a new base, is actually missing from these cells [34]. As a result of this lack of DNA repair capacity, sperm chromatin is vulnerable to oxidative attack with the result that oxidative DNA damage is commonly encountered in the spermatozoa of subfertile males $[35,36]$. The presence of $8 \mathrm{OHdG}$ is highly correlated with the generation of superoxide anion by these cells as well as the levels of DNA fragmentation [29]. Since the latter is associated with an array of adverse reproductive outcomes, such as failed fertilization, disrupted preimplantation development, miscarriage and diseases in the offspring, including cancer, resolving the causes of oxidative stress in the germ line is a matter of some urgency [37].

\section{Smoking}

One of the factors thought to be responsible for creating oxidative stress in the male germ line is smoking. Men who smoke heavily exhibit systemic oxidative stress characterized by low levels of vitamin $\mathrm{C}$ and $\mathrm{E}$ in both the general circulation and in seminal plasma $[38,39]$. As a consequence of this stress, their spermatozoa exhibit high levels of DNA fragmentation and 8OHdG expression. Such DNA damage does not dramatically impair the fertility of male smokers; however, it does compromise the health and well-being of their offspring. A recent meta-analysis addressing this question found a significant correlation between paternal smoking and the incidence of childhood cancer [40]. This is a very important weapon in the armamentarium of those who wish to discourage smoking. In addition to effects on the perpetrator, such as lung cancer and coronary heart disease, we should also recognize that smoking affects the health trajectory of our children and, because the damage is in the germ line, has the potential to impact on the well-being of their descendents.

\section{Age}

Age is another factor associated with oxidative stress in the male germ line. Unlike the precipitous decline of female fertility between 35 and 40, men do not stop producing spermatozoa as they age and can reproduce in their $80 \mathrm{~s}$ and 90s. However, the quality of these gametes becomes compromised, as men grow older. Thus, a man aged over the age of 35 will have three times the levels of DNA damage in his spermatozoa as a male below this age [41]. Studies in animal models such as the brown Norway rat and the senescence-accelerated mouse (SAMP8) demonstrate that this age-dependent increase in DNA damage is oxidatively induced [42,43]. Paternal aging is also associated with many different kinds of adverse clinical consequences downstream from conception, including elevated rates of miscarriage, increased incidences of dominant genetic disease, such as achondroplasia and Apert syndrome, and an enhanced risk of neuropathology in the offspring, including bipolar disease, autism, spontaneous schizophrenia and epilepsy $[35,44]$.

The increased incidence of diseases in the children of ageing fathers is associated with a general increase in mutational load [45]. It is possible that such mutations arise at the level of the spermatogonial stem cell and are a simple reflection of replication errors, possibly aided and abetted by the selection of mutations that give the germ cells an advantage during spermatogenesis, as appears to be the case with Apert syndrome [46,47]. An alternative suggestion is that the spermatozoa of ageing males carry damaged DNA into the oocyte at fertilization and activate a DNA repair process that precedes the S-phase of the first mitotic division $[18,48]$. If the oocyte should make any errors during this repair process, they could easily account for the increased mutational load seen in the offspring of men as they age. Which of these alternative mechanisms predominates as men age is unknown. Whatever mechanisms are involved, it is clear that the spermatozoa of ageing males are, directly or indirectly, a major source of mutations that impact on the health trajectory of their offspring.

\section{Apoptosis and antioxidants}

Age and smoking are only two of the many factors known to result in the creation of oxidative stress within the germ line and there are many others, including radiofrequency electromagnetic radiation, insecticides, pesticides, metals, cryptorchidism, testicular torsion, varicocele, hyperthyroidism, diabetes, infection, physical exertion, endocrine disruption and retinoid exposure [49]. Such a range of environmental factors should all culminate in the induction of oxidative stress in the germ line and this may reflect the innate tendency of spermatozoa to respond to stress by defaulting to a truncated, intrinsic, apoptotic pathway featuring the generation of reactive oxygen species (ROS) by the sperm mitochondria [50]. Under normal circumstances, spermatozoa are prevented from defaulting to apoptosis by PI3 kinase. This enzyme generates phosphatidylinositol (3,4,5)-triphosphate, which binds to another kinase, AKT1 (RAC-alpha serine/threonine-protein kinase), and thereby effects the translocation of this enzyme to the plasma membrane, where it becomes activated by phosphorylation. The targets for AKT1-mediated phosphorylation include key proteins involved in the induction of apoptosis, such as the Bcl-2-associated death 
promoter protein (BAD), which is a pro-apoptotic member of the Bcl-2 gene family. As long as BAD is phosphorylated by AKT1, it is held in an inactive state by its 14-3-3 keeper protein. However, as soon as spermatozoa experience significant stress, the ability of the PI3 kinase-AKT1 pathway to maintain pro-apoptotic factors, such as $\mathrm{BAD}$, in an inactive state is compromised and the cells default to apoptosis.

The latter involves the activation of mitochondrial ROS generation, caspase activation and phosphatidylserine externalization much as one would observe in a somatic cell [50]. The major difference between spermatozoa and every other cell type contemplating suicide is that, in the former, the sperm nucleus is physically separated from the mitochondria and a majority of the cytoplasm. As a result, nucleases released from the mitochondria or activated in the cytoplasm cannot gain access to the sperm nucleus and induce the DNA fragmentation typical of apoptosis in somatic cells [50]. This is why all of the DNA damage seen in the male germ line appears to be oxidative in nature because the only component of the apoptotic pathway that can move from the midpiece, where the mitochondria are housed, to the nucleus in the sperm head, are highly diffusible, membrane permeant ROS, such as hydrogen peroxide (Figure 2).

The oxidative stress associated with apoptosis is, furthermore, a self-perpetuating cycle. Once oxidative stress is initiated, lipid peroxidation is induced because spermatozoa contain high concentrations of polyunsaturated fatty acids, particularly decosahexaenoic acid, containing six double bonds per molecule $[30,51,52]$. The latter are particularly vulnerable to free radical attack because the carbon hydrogen dissociation energies are lowest at bis-allylic methylene positions. As a result, the hydrogen abstraction event that initiates lipid peroxidation is promoted, generating a carbon centred lipid radical that then combines with oxygen to generate peroxyl $(\mathrm{ROO} \bullet)$ and alkoxyl $(\mathrm{RO} \bullet)$ radicals that, in order to stabilize, abstract hydrogen atoms from adjacent carbons. These chemical reactions create additional lipid radicals that then perpetuate the lipid peroxidation chain reaction culminating in the generation of small molecular mass electrophilic lipid aldehydes, such as 4-hydroxynonenal, acrolein and malondialdehyde. These electrophiles bind to proteins in the mitochondrial electron transport chain and disturb the regulated flow of electrons leading to electron leakage and yet more superoxide anion generation. In this way, spermatozoa experience a self-perpetuating lipid peroxidationmediated, ROS-induced-ROS-generation cycle that ultimately culminates in their death [53].

\section{Apoptosis and phagocytosis}

Such apoptotic death is probably the fate of all spermatozoa in the ejaculate apart from the single cell that fertilizes the oocyte. Such carefully controlled cellular senescence is important because, as far as both the male and female reproductive tracts are concerned, spermatozoa are antigenically foreign cells, potentially capable of inducing inflammation and even precipitating anaphylactic shock [54]! Thus, when hundreds of millions of spermatozoa become senescent, as in the vasectomized male or the post-insemination female, and massive leukocytic infiltration is induced, it is essential that the ensuing phagocytic process is characterized by silence, without the induction of ROS generation or the production of proinflammatory cytokines. By analogy to the silent phagocytosis seen in other cellular systems, the expression of apoptotic markers, such as phophatidylserine, on the surface of moribund spermatozoa is thought to play a critical role in the mediation of their silent, efficient removal from the reproductive tract by macrophages and neutrophils [55].

Given this susceptibility of the male germ line to oxidative stress, it has been proposed that antioxidants would represent a logical means of addressing DNA damage and impaired sperm function in subfertile males [56]. Although several antioxidant trials have been conducted, very few of them reach the gold standard of a properly randomised, double blind, placebo controlled cross-over trial. Thus, while the results of meta-analyses seem encouraging, in terms of reducing levels of DNA damage and the incidence of miscarriage, there is an urgent need for well conducted clinical trails in this area $[57,58]$.

\section{Conclusions}

Male infertility is a relatively common condition affecting a significant proportion of males of reproductive age. In a majority of men, sufficient numbers of spermatozoa are generated to achieve conception in vivo, but many of their spermatozoa have lost their competence for fertilization. The aetiology of this pathology is complex and involves a combination of genetic and environmental factors that culminate in a state of oxidative stress that compromises the fertilizing potential of these cells and the integrity of their DNA. In addition to the direct induction of DNA damage, such stress may also compromise the functionality of epigenetic regulators of embryonic development by: (a) the induction of oxidative damage in the bewildering variety of non-coding RNA species carried by spermatozoa and (b) the hypermethylation of key genes in the male germ line as a result of the ability of ROS to stimulate DNA-methyltransferase activity $[59,60]$. 
Resolution of the environmental factors responsible for inducing male infertility is critical if we are to take rational preventative measures. In this context, important issues that deserve attention include smoking and environmental exposures to electromagnetic radiation and endocrine disruptors. As far as genetic causes are concerned, we are still very much in the infancy of such studies, but there is a concern that the current high rate of recourse to assisted conception therapy may lead to the transmission of infertility-causing mutations to subsequent generations, further increasing the demand for reproductive technologies and creating a health burden for the future. If we are ever to address such issues, we shall need to understand much more about the conditions leading to oxidative stress and genetic damage in the male germ line and give the analysis of sperm differentiation and function the respect it deserves.

\section{Abbreviations}

8OHdG, 8-hydroxy,2'-deoxyguanosine; BAD, Bcl-2associated death promoter protein; ICSI, intracytoplasmic sperm injection; ROS, reactive oxygen species.

\section{Disclosures}

The author declares no disclosures.

\section{Acknowledgements}

The author gratefully acknowledges the support that he has received from the University of Newcastle, Hunter Medical Research Institute, the Australian Research Council and the National Health and Medical Research Council of Australia.

\section{References}

I. Hull MGR, Glazener CMA, Kelly NJ, Conway DI, Foster PA, Hunton RA, Coulson C, Lambert PA, Watt EM, Desai KM: Population study of causes, treatment and outcome of infertility. Brit Med J |985, 29|: | 693-7.

\section{FIOOOPrime}

\section{RECOMMENDED}

2. McLachlan RI, de Kretser DM: Male infertility: the case for continued research. Med J Aust 200I, I74: I I6-I I7.

\section{FlOOOPrime} RECOMMENDED

3. Dorman E, Bishai D: Demand for male contraception. Expert Rev Pharmacoecon Outcomes Res 2012, I2:605-13.

4. Aitken RJ, Hughes LM, Griffith R, Baker MA: Bridging the gap between male and female fertility control; contraception-ondemand. Contraception 2008, 78(Suppl 4):S28-35.

5. Hughes LM, Griffith R, Aitken RJ: The search for a topical dual action spermicide/microbicide. Curr Med Chem 2007, I4:775-86.

6. Cooper TG, Noonan E, von Eckardstein S, Auger J, Baker HW, Behre HM, Haugen TB, Kruger T, Wang C, Mbizvo MT, Vogelsong KM: World Health Organization reference values for human semen characteristics. Hum Reprod Update 2010, | 6:23 |-45.

\section{FIOOOPrime}

7. Seuanez HN, Carothers AD, Martin DE, Short RV: Morphological abnormalities in spermatozoa of man and great apes. Nature 1977, 270:345-7.

\section{FlOOOPrime}

RECOMMENDED

8. Short RV: (1997) The testis - the witness of the mating system, the site of mutation and the engine of desire. Acta Paediatr 1997, 86:3-7.

\section{FlOOOPrime}

\section{RECOMMENDED}

9. Carlsen E, Giwercman A, Keiding N, Skakkebaek NE: Evidence for decreasing quality of semen during the past $\mathbf{5 0}$ years. Brit Med J 1992, 305:609-13.

10. Irvine S, Cawood E, Richardson D, MacDonald E, Aitken J: Evidence of deteriorating semen quality in the United Kingdom: birth cohort study in $\mathbf{5 7 7}$ men in Scotland over I I years. Brit Med J 1996, 3 I 2:467-7|.

II. Aitken RJ: Falling sperm counts twenty years on: where are we now? Asian J Androl 2013, 15:204-7.

12. Fisch $\mathrm{H}$, Braun SR: Trends in global semen parameter values. Asian J Androl 2013, I5:169-73.

13. Lutz W, Qiang R: Determinants of human population growth. Philos Trans R Soc Lond B Biol Sci 2002, 357:1 197-210.

\section{FIOOOPrime}

14. Lutz W: Fertility rates and future population trends: will Europe's birth rate recover or continue to decline? Int J Androl 2006, 29:25-33.

\section{FlOOOPrime}

RECOMMENDED

15. Kitamura M, Matsumiya K, Koga M, Nishimura K, Miura H, Tsuji T, Matsumoto M, Okamoto Y, Okuyama A: Ejaculated spermatozoa in patients with non-mosaic Klinefelter's syndrome. Int J Urol 2000, 7:88-92.

\section{FlOOOPrime}

\section{RECOMMENDED}

16. Ferlin A, Garolla A, Foresta C: Chromosome abnormalities in sperm of individuals with constitutional sex chromosomal abnormalities. Cytogenet Genome Res 2005, I I I:3 10-6.

17. Rives N, Joly G, Machy A, Siméon N, Leclerc P, Macé B: Assessment of sex chromosome aneuploidy in sperm nuclei from 47, XXY and 46,XY/47, XXY males: comparison with fertile and infertile males with normal karyotype. Mol Hum Reprod 2000, 6:107-12.

\section{FIOOOPrime
RECOMMENDED}

18. Aitken RJ, Krausz C: Oxidative stress, DNA damage and the Y chromosome. Reproduction 200I, I 22:497-506.

19. Navarro-Costa P, Gonçalves J, Plancha CE: The AZFc region of the $Y$ chromosome: at the crossroads between genetic diversity and male infertility. Hum Reprod Update 2010, 16:525-42.

\section{FlOOOPrime}

\section{RECOMMENDED}

20. Totonchi M, Mohseni Meybodi A, Borjian Boroujeni P, Sedighi Gilani M, Almadani N, Gourabi H: Clinical data for 185 infertile Iranian men with Y-chromosome microdeletion. J Assist Reprod Genet 20I2, 29:847-53.

\section{FlOOOPrime}

\section{RECOMMENDED}

21. Krausz C, Degl'Innocenti S: Y chromosome and male infertility: update, 2006. Front Biosci 2006, I I:3049-6I. 
22. Wallerand H, Bernardini S, Chabannes E, Bittard H: Genetic cause of male infertility and molecular biology. Prog Urol 2003, 13:560-3.

23. McLachlan RI, O'Bryan MK: Clinical Review: state of the art for genetic testing of infertile men. J Clin Endocrinol Metab 2010, 95:1013-24

24. Linschooten JO, Verhofstad N, Gutzkow K, Olsen AK, Yauk C, Oligschläger $\mathrm{Y}$, Brunborg G, van Schooten FJ, Godschalk RW: Paternal lifestyle as a potential source of germline mutations transmitted to offspring. FASEB J 2013, 27:2873-9.

\section{FlOOOPrime \\ RECOMMENDED}

25. Sin HS, Barski A, Zhang F, Kartashov AV, Nussenzweig A, Chen J, Andreassen PR, Namekawa SH: RNF8 regulates active epigenetic modifications and escape gene activation from inactive sex chromosomes in post-meiotic spermatids. Genes Dev 2012. 26:2737-48

\section{FlOOOPrime
RECOMMENDED}

26. Barzideh J, Scott RJ, Aitken RJ: Analysis of the global methylation status of human spermatozoa and its association with the tendency of these cells to enter apoptosis. Andrologia 20 I2, [doi: I0. I I I / and. I2033]

27. Jenkins TG, Aston KI, Cairns BR, Carrell DT: Paternal aging and associated intraindividual alterations of global sperm 5-methylcytosine and 5-hydroxymethylcytosine levels. Fertil Steril 2013, [doi: pii:SO0 I5-0282(I3)00649-3. 10.1016/j.fertnstert.2013.05.039].

\section{FlOOOPrime}

\section{RECOMMENDED}

28. Sendler E, Johnson GD, Mao S, Goodrich RJ, Diamond MP, Hauser R, Krawetz SA: Stability, delivery and functions of human sperm RNAs at fertilization. Nucleic Acids Res 2013, 41:4104-17.

\section{FlOOOPrime}

\section{RECOMMENDED}

29. Aitken RJ, Curry BJ: Redox regulation of human sperm function: from the physiological control of sperm capacitation to the etiology of infertility and DNA damage in the germ line. Antioxid Redox Signal 20II, I4:367-8I.

30. Koppers AJ, Garg ML, Aitken RJ: Stimulation of mitochondrial reactive oxygen species production by unesterified, unsaturated fatty acids in defective human spermatozoa. Free Radic Biol Med 2010, 48: I 12-9.

31. Koppers AJ, De luliis GN, Finnie JM, McLaughlin EA, Aitken RJ: Significance of mitochondrial reactive oxygen species in the generation of oxidative stress in spermatozoa. J Clin Endocrinol Metab 2008, 93:3199-207.

32. Bennetts LE, Aitken RJ: A comparative study of oxidative DNA damage in mammalian spermatozoa. Molec Reprod Dev 2005, 71:77-87.

33. Kasprzak KS: Oxidative DNA and protein damage in metalinduced toxicity and carcinogenesis. Free Rad Biol Med 2002, 32:958-67.

34. Smith TB, Dun MD, Smith ND, Curry BJ, Connaughton HS, Aitken RJ: The presence of a truncated base excision repair pathway in human spermatozoa that is mediated by OGGI.J Cell Sci 20I3, 1 26: | 488-97.

35. Aitken RJ, Bronson R, Smith TB, De luliis GN: The source and significance of DNA damage in human spermatozoa; a commentary on diagnostic strategies and straw man fallacies. Mol Hum Reprod 2013, in press.

36. Aitken RJ, De luliis GN, Finnie JM, Hedges A, McLachlan RI: Analysis of the relationships between oxidative stress, DNA damage and sperm vitality in a patient population: development of diagnostic criteria. Hum Reprod 2010, 25:24I5-26.

37. Aitken RJ, Jones KT, Robertson SA: Reactive oxygen species and sperm function-in sickness and in health. J Androl 2012, 33:1096-106
38. Fraga CG, Motchnik PA, Wyrobek AJ, Rempel DM, Ames BN: Smoking and low antioxidant levels increase oxidative damage to sperm DNA. Mutat Res 1996, 35 I:199-203.

\section{FlOOOPrime}

\section{RECOMMENDED}

39. Fraga CG, Motchnik PA, Shigenaga MK, Helbock HJ, Jacob RA Ames BN: Ascorbic acid protects against endogenous oxidative DNA damage in human sperm. Proc Natl Acad Sci USA 1991, 88: $11003-6$.

\section{FIOOOPrime
RECOMMENDED}

40. Lee KM, Ward MH, Han S, Ahn HS, Kang HJ, Choi HS, Shin HY, Koo HH, Seo Jl, Choi JE, Ahn YO, Kang D: Paternal smoking, genetic polymorphisms in CYPIAI and childhood leukemia risk. Leuk Res 2009, 33:250-8.

\section{FlOOOPrime}

\section{RECOMMENDED}

41. Singh NP, Muller CH, Berger RE: Effects of age on DNA doublestrand breaks and apoptosis in human sperm. Fertil Steril 2003, 80: $1420-30$.

\section{FlOOOPrime}

RECOMMENDED

42. Paul C, Nagano $M$, Robaire $B$ : Aging results in differential regulation of DNA repair pathways in pachytene spermatocytes in the Brown Norway rat. Biol Reprod 20II, 85:1269-78.

\section{FlOOOPrime} RECOMMENDED

43. Smith TB, De luliis GN, T. Lord T, Aitken RJ: The senescenceaccelerated mouse prone 8 (SAMP8) as a model for oxidative stress and impaired DNA repair in the male germ line. Reproduction 2013, in press.

44. Aitken RJ, De luliis GN, McLachlan RI: Biological and clinical significance of DNA damage in the male germ line. Int J Androl 2009, 32:46-56.

45. Kong A, Frigge ML, Masson G, Besenbacher S, Sulem P, Magnusson G, Gudjonsson SA, Sigurdsson A, Jonasdottir A, Jonasdottir A, Wong WS, Sigurdsson G, Walters GB, Steinberg S, Helgason H, Thorleifsson G, Gudbjartsson DF, Helgason A, Magnusson OT, Thorsteinsdottir U, Stefansson K: Rate of de novo mutations and the importance of father's age to disease risk. Nature 2012, 488:47|-5.

\section{FlOOOPrime}

\section{RECOMMENDED}

46. Yoon SR, Choi SK, Eboreime J, Gelb BD, Calabrese P, Arnheim N: Age-dependent germline mosaicism of the most common Noonan syndrome mutation shows the signature of germline selection. Am J Hum Genet 2013, 92:917-26.

47. Goriely A, McGrath J, Hultman CM, Wilkie AO, Malaspina D: "Selfish spermatogonial selection": a novel mechanism for the association between advanced paternal age and neurodevelopmental disorders. Am J Psychiatry 2013, 170:599-608.

48. Aitken RJ, Koopman P, Lewis SE: Seeds of concern. Nature 2004, 432:48-52.

49. Aitken RJ, Roman SD: Antioxidant systems and oxidative stress in the testes. Oxid Med Cell Longev 2008, I:I5-24.

50. Koppers AJ, Mitchell LA, Wang P, Lin M, Aitken RJ: Phosphoinositide 3-kinase signalling pathway involvement in a truncated apoptotic cascade associated with motility loss and oxidative DNA damage in human spermatozoa. Biochem J 2011 , 436:687-98.

5I. Jones R, Mann T, Sherins R: Peroxidative breakdown of phospholipids in human spermatozoa, spermicidal properties of fatty acid peroxides, and protective action of seminal plasma. Fertil Steril 1979, 3 I:53 I-7.

52. Ollero M, Gil-Guzman E, Lopez MC, Sharma RK, Agarwal A Larson K, Evenson D, Thomas AJ Jr, Alvarez JG: Characterization of subsets of human spermatozoa at different stages of 
maturation: implications in the diagnosis and treatment of male infertility. Hum Reprod 2001, 16:1912-21.

53. Aitken RJ, Whiting S, De luliis GN, McClymont S, Mitchell LA, Baker MA: Electrophilic aldehydes generated by sperm metabolism activate mitochondrial reactive oxygen species generation and apoptosis by targeting succinate dehydrogenase. J Biol Chem 2012, 287:33048-60.

54. Nist GC, von den Driesch P: Human seminal plasma allergy-a rare cause of recurrent anaphylaxis. J Dtsch Dermatol Ges 2007, 5:34-6.

FlOOOPrime RECOMMENDED

55. Rossi AG, Aitken RJ: Interactions between leukocytes and the male reproductive system. The unanswered questions. Adv Exp Med Biol 1997, 424:245-52.
56. Gharagozloo P, Aitken RJ: The role of sperm oxidative stress in male infertility and the significance of oral antioxidant therapy. Hum Reprod 2011, 26:1628-40.

57. Greco E, lacobelli M, Rienzi L, Ubaldi F, Ferrero S, Tesarik J: Reduction of the incidence of sperm DNA fragmentation by oral antioxidant treatment. J Androl 2005, 26:349-53.

58. Showell MG, Brown J, Yazdani A, Stankiewicz MT, Hart RJ: Antioxidants for male subfertility. Cochrane Database Syst Rev 20II, CD0074II.

59. Kang KA, Zhang R, Kim GY, Bae SC, Hyun JW: Epigenetic changes induced by oxidative stress in colorectal cancer cells: methylation of tumor suppressor RUNX3. Tumour Biol 2012, 33:403-12.

60. Zhang R, Kang KA, Kim KC, Na SY, Chang WY, Kim GY, Kim HS, Hyun JW: Oxidative stress causes epigenetic alteration of CDXI expression in colorectal cancer cells. Gene 2013, 25(524):2। $4-9$. 